\title{
Forms of Social Capital on Halal Tourism in Bandung
}

\author{
Moh. Dulkiah \\ UIN Sunan Gunung Djati Bandung \\ Email:moh.dulkiah@uinsgd.ac.id
}

\begin{abstract}
This article focuses on the social capital of local communities in the development of halal tourism. This article aims to understand the social capital of local communities in their efforts to develop halal tourism in Bandung, West Java. The paradigm approach used is qualitative with the method of extracting data in-depth interviews and documentation review methods. This research found that the potential of local communities in the development of halal tourism lies in the trust and values that develop in the community. Trust is focused on the emergence of expectations from the community towards the management of sharia-based tourism objects. While values are inherent in positive local virtues in tourism development. This study concludes that halal tourism correlates with the expectations and values that develop in local communities.
\end{abstract}

Keyword: Social Capital, Local Communities, Halal Tourism, Value.

\section{A. INTRODUCTION}

Indonesian society has a unique character. As we know that Indonesia is a country with the largest Muslim majority in the world. Based on data from Global Religion 2019, in 2010 the number of Indonesian Muslims was 209.12 million people or $87.17 \%$ of the total population of 239.89 million people. 2020 is predicted to continue to increase to 263.92 million people (Global Religious Future, 2020). This is certainly an opportunity for the development of halal tourism in Indonesia.

In recent years, government has been very serious in galvanizing halal tourism in order to increase the number of tourists who will impact on economic benefits. The plan, in 2026, the government targets the visit of Muslim tourists to reach 230 million people with shopping transactions of up to USD 180 billion. One proud phenomenon, according to the Global Muslim Travel Index (GMTI). Indonesia is able to become the best halal tourist destination in 2019, outperforming 130 other destinations worldwide (Nasrulhak, 2019).

The condition of halal tourism nationally is still not optimal. In fact, if worked on more seriously, the potential for the development of halal tourism is huge. Based on data from the Central Statistics Agency and the Ministry of Tourism's Data and Information Center, the number of tourists from several Middle Eastern countries based on nationality, namely Bahrain by 98 people in 2013 to 99 people in 2014 (up 1.02 per cent), Egypt by 675 people in 2013 to 733 people in 2014 (up 8.59 per cent), and the United Arab Emirates by 1,322 people to 1,428 people (up 8.02 per cent), while Saudi Arabia recorded a growth rate down 3.90 per cent from 7,522 people ( in 2013) to 7,229 people in 2014 (Permadi et al., 2018). 
As the country with the largest Muslim population in the world, Indonesia seeks to continue developing Islamic tourism in the country. The Ministry of Tourism develops sharia tourism including four types of tourism business components, namely hospitality, restaurants, travel agencies or travel services, and spas. There are 13 (thirteen) provinces prepared by Indonesia to become sharia tourism destinations, namely West Nusa Tenggara (NTB), Nangroe Aceh Darussalam, West Sumatra, Riau, Lampung, Banten, DKI Jakarta, West Java, Central Java, Yogyakarta, East Java, South Sulawesi and Bali (Indonesia Travel, 2013 in Al Hasan 2017).

West Java as one of the regions with the best halal tourism potential is considered as one of the leading halal tourism destinations (Setiawan, 2019). West Java Provincial Government itself has set five areas that must be maximized, namely, Bogor, Sukabumi, Karawang, Metro Bandung, Greater Bandung, and Ciayumajakuning (Cirebon, Indramayu, Majalengka, Kuningan) and Cianjur (Deny 2019). Furthermore, the proof is that in 2016, one of the hotels in Bandung became the best halal hotel in the world, the Hotel The Trans Luxury Hotel Bandung.

Research on halal tourism has also been carried out by researchers. Jaelani (2017) examines halal tourism as part of the national tourism industry while positioning Indonesia as the centre of halal tourism in the world. For example, pilgrimage tours that have long been present in Indonesia as religious tourism. However, the development of global Islam must be supported by modern changes in tourist objects, including hotels, to marketing. In addition, Pratiwi, Dida, and Sjafirah (2018), discussed efforts to develop halal tourism in Indonesia requiring support and care from various parties. In this case, it is necessary to raise awareness and collaborate with related institutions to build awareness building for stakeholders and the wider community. Furthermore, the development of halal tourism must also be supported by local cultural wisdom in order to continue to contain cultural values and values. Islam (Manara \& Larasati, 2018).

Most researchers link halal tourism from cultural, economic and political aspects. While the development of halal tourism from the aspect of social capital has not been done much by researchers. Whereas in reality, the development of halal tourism requires the social capital of local communities so that its success can be right on target and have a major impact on the wider community. Social capital as one of the concepts in social terminology has been widely discussed by. The study of social capital has been highlighted by several experts. Uphoff (1999) sees more as the accumulation of assets of various types of social cognitive, psychological, cultural, institutional, and mutually beneficial behaviours. Social capital is attached to fellowship, sympathy, social relations and social life in social units. Coleman (1999) sees social capital in 3 (three) forms, namely: obligations and expectations, the ability of information channels, and norms. Bourdieu While Putnam (2000) and Francis Fukuyama (2002) are more concerned with trust, network, and norms/values. 
Based on the explanation above, the authors try to set a study objective as an effort to understand the social capital of local communities in the development of halal tourism in the area of Bandung, West Java.

\section{B. LITERATURE REVIEW}

Halal tourism is a new terminology that is not widely known by the public. The term halal tourism links the term tourism as a visiting activity with the term halal. Halal is a term that is absorbed from Arabic, which means it is permitted according to sharia (Islamic law). Muslims are required to follow Sharia in practising their religion as a way of life. Sharia covers all aspects of Muslim life, from birth to death. Because of these principles, Muslims always make an effort to follow what has been established in sharia, including in the field of travel and tourism. Some Muslims, when travelling - both in Muslim and non-Muslim countries - prefer to use services, facilities, and activities that are in accordance with Islamic principles. Specifically related to food, there is a need for Muslims to consume halal food, which is in accordance with sharia. This has motivated the tourism industry to meet the needs of Muslim tourists by developing halal tourism. Before looking at the definition of halal tourism, let's look at the definition of tourism (Khoiriati et al., 2018).

According to the UNWTO, tourism is defined as the activities of people who travel to and live in places outside their usual environment for no more than one year in a row for vacation, business and other purposes (McIntosh, Goeldner, and Ritchie 1995). This definition refers to tourism in general. Combining the term "Halal" to form "Halal tourism," the definition of halal tourism refers to "attractions or actions permitted according to Islamic teachings to be used or involved by Muslims in the tourism industry" (Battor \& Ismail, 2016). For example, Muslim travellers visiting Japan have difficulty finding halal food and prayer rooms. Therefore, the Japanese government, such as the Kansai International Airport, has facilitated Muslim travellers with halal food and prayer rooms at the airport (Battor and Ismail, 2016). In addition, halal tourism is a concept that emerges today.

Scientists such as El-Gohary (2016), assert that halal tourism refers to offering tour packages that are in line with Islamic or Sharia law. He stressed that halal tourism can handle halal hotels, halal food, halal logistics, and halal financial activities (eg using Islamic banks for transactions). Therefore, we argue that halal tourism is a concept of tourism management activities that are permitted by Islamic law. In other words, halal tourism products and activities must follow all guidance from Allah (Allah) and the Prophet Muhammad (Wardi, Abror, \& Trinanda, 2018).

El-Gohary (2016) found several main attributes of halal tourism such as religious facilities, halal food, no prostitution, and no alcohol and no gambling. Then, Battor and Ismail (2016) examined four main attributes of halal tourism, including religious facilities, halal, general Islamic morality, and free from alcoholic drinks and gambling. Battor and Ismail (2016) mention that worship facilities, such as mosques, qibla direction and ablution facilities (wudu), are important elements 
for Muslim tourists when they are on vacation. Halal refers to Halal facilities, such as kitchens, tableware, and halal food. General Islamic morality refers to general rules in Islam such as dress codes, prohibition of prostitution, and censoring sex scenes on TV. The last attribute is the regulation regarding alcoholic drinks and free from gambling. Battor and Ismail (2016) also argue that Islamic values and government regulations are important factors for deciding there is no alcohol and no gambling in resorts.

Zamani Farahani and Anderson (2010) define halal tourism as Muslim travel activities when moving from one place to another or when they are in a place outside their normal residence for a period of less than one year and to engage in activities with Islamic motivation. It should be noted that tourism activities in Islam must be in accordance with generally accepted Islamic principles, namely halal (Zamani-Farahani and Henderson 2010).

Halal tourism is a new product for the world's Muslim and non-Muslim markets. Zulkifli in (Akyol and Kilinc 2016), formulated the halal market classified into three categories, namely: food, lifestyle (cosmetics and textiles), and services (tour packages, financial, transportation). According to Pavlove in Hall and Prayag (2020), halal tourism or Islamic tourism is defined as tourism and hospitality which are also created by consumers and producers in accordance with Islamic teachings. Many countries in the world of Islam are taking advantage of the increasing demand for Muslim-friendly travel services. Meanwhile, according to (Achyar, Schmidt-Vogt, and Shivakoti 2015), the existence of halal tourism is as follows:

"Halal tourism is extended services. If nothing is sought, if there is one, it can make a sense of security. Wisatahalal can go hand in hand with others. Its nature can be: complementary, can be like the product itself. For example, there is a halal hotel, meaning that people who are looking for hotels that guarantee the halal of their products will get wider options. This is actually expanding the market, not reducing. From what did not exist, so there ".

In the 2015 Focus Group Discussion (FGD) on Halal Tourism and Lifestyle at the Jakarta Convention Center, Senayan, Jakarta, Tuesday (12/5). Minister of Tourism Arief Yahya conveyed that halal tourism must be carried out universally or "Universal Tourism", this is because halal tourism is not the only culinary. There are other industries such as fashion, finance, health and so on. So "Universal" has represented all tourists who come to Indonesia, both Muslim and non-Muslim (Yuliaty and Putri, 2019).

According to Adinugraha, Sartika, and Kadarningsih (2018), halal tourism is not only religious tourism, but it is also broader than that stipulated in Islamic sharia values. As recommended by the World Tourism Organization (UNWTO), sharia consumers are not only Muslims but also non-Muslims who want to enjoy local wisdom.

In addition, Eko Nursanty (2012), divided halal tourism into three aspects as follows: 


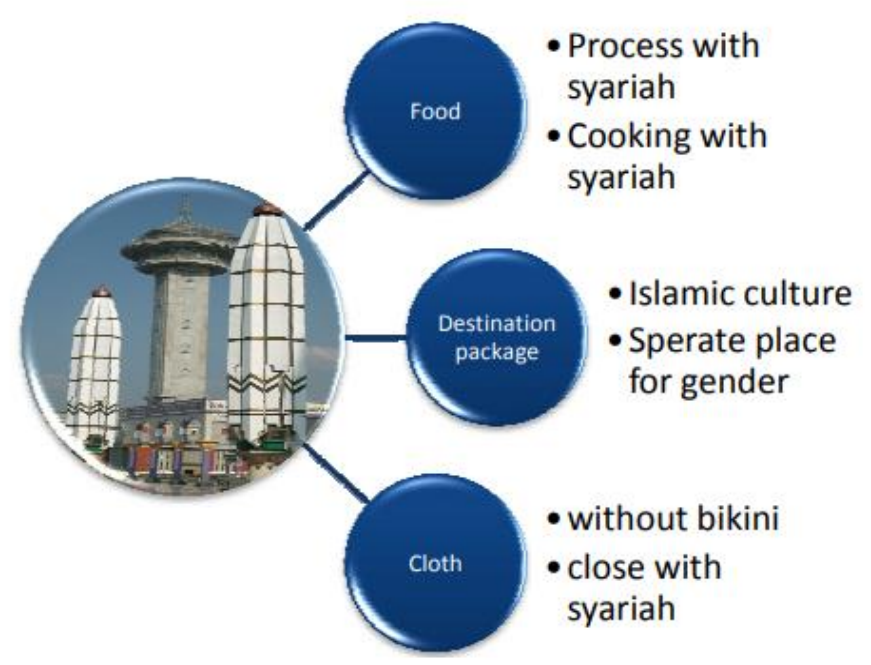

Figure 1 Aspects of Halal Tourism

Source: Nursanty (2012)

President of the Islamic Nutrition Council of America, Muhammad Munir Caudry, said that halal tourism is a new concept, but not religious tourism such as Umrah or Hajj. Halal tourism caters to tourists, tailoring holiday styles to suit the needs and demands of Muslim tourists. In this case, hotels that provide halal tourism do not serve alcoholic drinks and have separate spa pools between men and women (Wuryasti, 2013).

Meanwhile, halal tourism according to the Islamic Tourism Center Malaysia is defined as "every activity, event and experience carried out in a state of travel in accordance with Islam" (Wahidati and Sarinastiti 2018). Henderson (2016), sees how the concept of tourism carried out by Muslims makes religion an important consideration, as it is not a primary motivation. From this resolution, the similarity can be drawn, namely, Islamic tourism is tourism carried out in accordance with the Shari'a or the provisions in Islam.

In addition, according to the Organization of the Islamic Conference (OIC) using Islamic Tourism as a terminology based on Islam and tourism in the Qur'an 29:20 which encourages humans to travel on earth to take lessons from God's creation and take His grace. Islamic tourism is intended as a tourist trip aimed at providing tourist services and facilities for Muslim tourists in accordance with Islamic principles (Subarkah 2018; Izet et al. 2020).

There is a set of standard factors in terms of administration and management for all tourists that can be characteristic, namely: (Chookaew et al. 2015: 277-279; Adinugraha, Sartika, and Kadarningsih 2018). Halal tourism in terms of services must be in accordance with the principles of the whole Muslim; Guides and staff must have discipline and respect Islamic principles; Approve all activities so as not to conflict with Islamic principles; Buildings must be in accordance with Islamic principles; Restaurants are required to adhere to international halal service standards; Transportation services must have a protection system security; There are 
places provided for all Muslim tourists who carry out religious activities; and Bandar to places that are not opposed to Islamic principles.

\section{METHOD}

This research uses a qualitative approach and is directed to use descriptive data mining through in-depth interviews and documentation studies. This research was conducted in the Bandung area, West Java Province, Indonesia. Bandung discussed in this study covers Bandung City, Bandung Regency, West Bandung, and Cimahi City. This is a tourist attraction in this study. The type of data collected in this study consists of actions and actions taken by tourists, tour managers, local communities, and the city government of Bandung represented by the Department of Tourism. The main data source in this study is an explanation of the four components of the source.

The data that has been obtained is then reduced, classified and arranged according to the study preparation. The author then submits descriptive data both sourced from primary data (results of in-depth interviews with tourists, tourism managers, local communities, and tourism agencies) as well as secondary data (books, magazines, bulletins, mass media and electronics, manuscripts, and reports).

\section{RESULT AND DISCUSSION}

The Bandung region is an urban and rural area which is at the centre of the government of West Java Province. In this Bandung area, there are many historic sites that describe the beauty of the city, so Bandung in the colonial period was known as Paris Van Java. The beautiful city until now remains pleasant Bandung has an extraordinary attraction for tourists. The land structure in Bandung supports the plateau which presents beautiful panoramas and is a favourite of tourists. Bandung is never empty of visitors, including visitors from Muslim circles.

No wonder the Ministry of Tourism questions Bandung as one of the National priority halal tourism destinations in 2019. Halal tourism is a lifestyle that provides Muslim tourists to tourist destinations. With the halal tour, Muslim tourists find it easy to get needs ranging from getting halal food and drinks, performing worship, to meeting their personal needs. The cause with halal tourism, given tourists about tourist destinations that fit the needs according to Islamic law.

The purpose and benefits of halal are to increase the fulfilment of tourists' needs while taking into account the requirements and values in Islam. In addition to enjoying the beauty of nature, halal tourism can also add insight to tourists. The requirements for taking a halal tour are Islamic values that must be carried out and do not need to be directed at the disobedience process which is forbidden by religion. From the legal aspect, halal tourism is suitable for the purpose of da'wah and reflects the authority of God that is in the tourist attraction. A tourist in his journey always begins with praying. Likewise, during travel activities, tourists always deliver ethics. In addition, guides are interested in providing enlightenment 
and direction for tourists to always uphold religious values and provide halaloriented facilities.

Indeed, in Bandung, not all tourist attractions have conformity with Muslim tourists. Some tourist sites are equipped with facilities such as prayer rooms or food in accordance with Islamic law. In addition, there are also many tourist sites that do not provide enough air for washing and cleaning, toilets provided are designed only to use tissue.

Through the launching of halal tourism, several supporting facilities are tailored to the needs of Muslims. Culinary tourism such as restaurants will get halal legitimacy or certification from the Indonesian Ulema Council as an institution entitled to halal certification. In tourist attractions are also provided directions to the mosque until the different toilets between men and women are equipped with adequate air supply. Therefore, the general criteria for sharia tourism include: first, having an orientation for public good. Second, have calm, refreshment, and calmness. Third, avoiding polytheism and superstition. Fourth, free from immorality. Fifth, secure security and comfort. Sixth, protecting the environment. Seventh, respect for socio-cultural values and local wisdom.

In Bandung, halal tourism trends have been developed since the last 10 years. But as a city that represents Islam, halal tourism is a must. Halal tourism is projected to attract tourists not only domestically, but also internationally. Foreign tourist arrivals to Malaysia, Singapore and the Middle East to Bandung will increase with the existence of halal-based tourism objects. According to information from the Culture and Tourism Office of the City of Bandung, there are currently around 300,000-500,000 Malaysian tourists visiting Bandung. The tourism office also predicts that with halal tourism, tourist arrivals from Malaysia will increase by around $10 \%$.

Bandung has the potential to become a world-class tourist destination. This can be seen from the variety of attractions that are usually offered to tourists. The potential for developing halal tourism in Bandung is promising. Tourism has become a business that many businesses are eyeing for tourism. For example, there are several tourist attractions that represent Muslims, including First, De'Ranch which is on Jalan Maribaya No. 17, Kayuambon, Lembang. This place is one of the family tourist destinations that carries the theme of Cowboy. Activities that can be done at this tourist destination are horse riding, riding a Delman, enjoying air games, and halal cuisine. De'Ranch has provided a place for wudhu and mushola as well as representative facilities for Muslims. Secondly, Trans Studio Bandung, located at Jalan Gatot Subroto No. 289, Cibangkong, Batununggal. This place was built on 4.2 hectares and became the most complete shopping area in Bandung. The reason is the mall and hotel, Theme Park, Mega Tower, and a comfortable mosque. Third, the Lembang Dairy Farm which is a tourist area is managed by a group with the Sausage House, the Floating Market and De'Ranch. Fourth, Strawberry house which offers halal cafes, inns and culinary that applies the halal principle. Fifth, Panghegar Swimming Pool which classifies female swimmers and male swimmers. 
There are still many halal tourism destinations in Bandung which cause Bandung to be a warehouse for tourism.

Based on a closed tourism interview with tourists, tourism potential in Bandung discusses good and tourists appreciate this halal tourism visit. The development of halal tourism is clearly very important for business people in the industrial field. In addition, halal tourist destinations have diverse support. Bandung is a leading city in West Java. Even in 2013, the City Hall of the Ministry of Tourism set 13 provinces to become the leading halal tourist destination West Nusa Tenggara NTB Nanggroe Aceh Darussalam West Sumatra Riau Lampung Banten DKI Jakarta West Java Central Java Yogyakarta East Java South Sulawesi and Bali Indonesia travel, 2013, the Province West Java relies on Bandung as the heart of halal tourism destinations.

The development of halal tourism is also inherent in the creative industry, specifically in the provision of guides who have knowledge of Islamic values such as Muslim spas, Sharia salons, and religious tourism travel agencies. The creative industry in supporting this halal plan is related to Islam which regulates human relations both from action relations and religious relations. A guide needs to have knowledge about halal travel destinations. Cause a tourist gets information about tourist sites through guides. Tour guides also need to invite tourists about badness and not the facilities to be addressed by tourists.

For tourism groups or families, the creative industry is presented in a journey that emphasizes the moral aspects in Islam. This tourist bureau provides Securities which continue to finance tourists by providing packages for tourists. From the aspect of education, guides who have the ability in the field of Sharia can provide enlightenment and direction to tourists in determining tourist attractions and tourist traps. this becomes important because the task of the guide is to give instructions to tourists in conducting tours that are inseparable from the values of Islamic tourism is a tourist attraction from tourists who can save tourists from how to buy immoral assistance.

Community social capital in the development of halal tourism that results in the management of tourism in the awareness of upholding Islamic values with tourists for actions that attract disobedience and declaration; start Islamic principles start from the selection of tourist destinations and tourist activities; and equipping tourist facilities with signs and worship facilities for Muslims. In the provision of religious facilities, most of the managers of restaurants, lodging, and tourism objects provide together with the ministry of religion to determine the direction of the mosque's prayer centre and mosque. Also, design accommodation with a wudhu provision system and purify with the sharia system in water management.

Construction of trust as a type of social capital that involves tourists, tourism managers, and local communities. The emergence of trust in tourists After tourists have experience in travelling. The trip gladly accepts the services provided by tour operators who are impressed with the local community because it is safe and 
comfortable with a comfortable trip. This satisfaction then gives rise to a pre-existing trust. Not only that, visitors will also discuss their visiting experiences with others.

Forms of social capital that emerge appear attached to the virtues of the local community. Local people in Bandung have values to determine and care for other people which are manifested in the form of sabilulungan. Sabilulungan value is a form of relationship that helps and helps each other in society both internal and external communities. Please help, mutual assistance and mutual assistance are manifested in daily life in all aspects of life. This local virtue value can make halal tourism in Bandung doable.

The main obstacle in the development of halal tourism is the unavailability of halal tourism guidelines. This will support the management of halal tourism for tourists. The government and private institutions support the drive for the development of halal tourism.

\section{E. CONCLUSION}

The social capital of the local community (sunda) in the development of halal tourism in Bandung appears in the relationships and trust between individuals formed in local virtues in the form of "sabilulungan" values. This sabilulungan value reflects the habits and traditions of the local community. Through the relationship of trust and sabilulungan values, the development of halal tourism in the city of Bandung can be run and managed. Local people who respect Islam, have values that support each other and are not fanatical about other tribes and religions.

Halal tourism in Bandung which is mostly located in the highlands has its own charm. However, this charm does not have great significance if the local community does not support it. The social capital of the local community supports in supporting halal tourism in Bandung. Hospitality and community care become an important part in the development of halal tourism in Bandung.

\section{ACKNOWLEDGMENT}

The author agrees with many thanks to the Department of Tourism, tourism managers, and the local community for providing information and helping in the research process. The author also thanks the Faculty of Social and Political Sciences (FISIP) Sunan Gunung Djati University in Bandung and the Makassar Ministry of Education and Training Center for allowing the author to conduct research.

\section{REFERENCES}

1. Achyar, E., Schmidt-Vogt, D., \& Shivakoti, G. P. (2015). Dynamics of the multistakeholder forum and its effectiveness in promoting sustainable forest fire management practices in South Sumatra, Indonesia. Environmental Development, 13, 4-17.

2. Adinugraha, H. H., Sartika, M., \& Kadarningsih, A. (2018). Desa wisata halal: konsep dan implementasinya di Indonesia. Human Falah, 5(1), 28-48.

3. Akyol, M., \& Kilinç, Ö. (2014). Internet and Halal Tourism Marketing. Electronic 
Turkish Studies, 9(8), 171-186.

4. Al Hasan, F. A. (2017). Penyelenggaraan Parawisata Halal Di Indonesia (Analisis Fatwa DSN-MUI Tentang Pedoman Penyelenggaraan Pariwisata Berdasarkan $\begin{array}{llll}\text { Prinsip Syariah). } & \text { al-Ahkam, 2(1): 59-77. }\end{array}$ https://www.researchgate.net/publication/323960421.

5. Battour, M., \& Ismail, M. N. (2016). Halal Tourism: Concepts, Practises, Challenges and Future. Tourism Management Perspectives, 19, 150-54. http://dx.doi.org/10.1016/j.tmp.2015.12.008.

6. Bourdieu, P. (2002). The Forms of Capital. Readings in Economic Sociology, 280291.

7. Coleman, J. S. (1990). Foundations of Social Theory. Cambridge MA: Harvard University.

8. Chookaew, S., Chanin, O., Charatarawat, J., Sriprasert, P., \& Nimpaya, S. (2015). Increasing halal tourism potential at Andaman Gulf in Thailand for Muslim country. Journal of Economics, Business and Management, 3(7), 739-741.

9. Deny, S. (2019). Jawa Barat Jadi Destinasi Wisata Halal Unggulan. Retrieved from https://www.liputan6.com/bisnis/read/3949751/jawa-barat-jadi-destinasi-wisatahalal-unggulan.

10. El-Gohary, H. (2016). Halal Tourism, Is It Really Halal?. Tourism Management Perspectives, 19, 124-30. http://dx.doi.org/10.1016/j.tmp.2015.12.013.

11. Global Religious Future. 2020. The Future of World Religions: Population Growth Projections, 2010-2050. Retrieved from http://globalreligiousfutures.org/countries/indonesia\#/?affiliations_religion_id=0 \&affiliations_year=2020\&region_name=All Countries\&restrictions_year=2016.

12. Hall, M. C., \& Prayag, G. (2020). The Routledge Handbook of Halal Hospitality and Islamic Tourism. New York: Rotledge.

13. Goeldner, C. R., \& Ritchie, J. B. (2007). Tourism principles, practices, philosophies. New York: John Wiley \& Sons.

14. Henderson, J. C. (2016). Halal Food, Certification and Halal Tourism: Insights from Malaysia and Singapore. Tourism Management Perspectives, 19, 160-64. http://dx.doi.org/10.1016/j.tmp.2015.12.006.

15. Islamy, D. I., NurAnnisa, M., \& Harahap, I. N. (2020). Potential and Prospects of Halal Tourism in Improving Regional Economy (Case Study: Ciletuh Geopark, Sukabumi-West Java). TSARWATICA (Islamic Economic, Accounting, and Management Journal), 1(2), 1-9.

16. Jaelani, A. (2017). Halal tourism industry in Indonesia: Potential and prospects. International Review of management and Marketing, 7(3).

17. Khoiriati, S. D., Krisnajaya, I. M., \& Dinarto, D. (2018). Debating halal tourism between values and branding: a case study of Lombok, Indonesia. KnE Social Sciences, 3(5), 494-515.

18. Manara, A. S., \& Larasati, P. P. (2018). Implementasi Nilai-Nilai Kearifan Lokal Nusantara dalam Pengembangan Indonesia Halal Tourism. Jurnal Et-Tijarie 5(2).

19. Nasrulhak, A. (2019). Indonesia Nomor Satu Wisata Halal, Ini Daftar Lengkap 10 Top 
GMTI. Retrieved from https://travel.detik.com/travel-news/d-4503350/indonesianomor-satu-wisata-halal-ini-daftar-lengkap-10-top-gmti.

20. Nursanty, E. (2012). Halal Tourism, The New Product In Islamic Leisure. Department of Architecture; University of 17 Agustus 1945 (UNTAG) Semarang, Indonesia, E-mail: 1945: 1-12.

21. Permadi, L. A., Darwini, S., Retnowati, W., \& Wahylina, A. (2018). Pendekatan Unique Point Selling (UPS) Dalam Reformulasi Strategi Pemasaran Pulau Gili Trawangan Pasca Gempa. Jurnal Sosial Ekonomi dan Humaniora, 4(2).

22. Pratiwi, S. R., Susanne, D., \& Sjafirah, N. A. (2018). Strategi Komunikasi Dalam Membangun Awareness Wisata Halal di Kota Bandung. Jurnal Kajian Komunikasi 6(1): 78 .

23. Setiawan, B. (2019). Pariwisata Halal Indonesia Naik 45 Persen, Ini Kiat Kemenpar. Tempo.co.

24. Subarkah, A. R. (2018). Potensi Dan Prospek Wisata Halal Dalam Meningkatkan Ekonomi Daerah (Studi Kasus: Nusa Tenggara Barat). Jurnal Sospol, 4(2), 49-72.

25. Uphoff, N. (1999). Understanding Social Capitakl: Learning from the analysis and experience of Participation. Washington D. C.: The World Bank.

26. Wahidati, L., \& Sarinastiti, E. N. (2018). Perkembangan Wisata Halal di Jepang. Jurnal Gama Societa, 1(1), 9-19.

27. Wardi, Y., Abror, A., \& Trinanda, O. (2018). Halal tourism: antecedent of tourist's satisfaction and word of mouth (WOM). Asia Pacific Journal of Tourism Research, 23(5), 463-472. https://doi.org/10.1080/10941665.2018.1466816.

28. Wuryasti, F. (2013). Halal Tourism, a New Concept of Tourism Activities in Indonesia.

29. Yuliaty, K., \& Putri, S. (2019). Wisata Halal Muslim Milenial. Jurnal Common 3(2).

30. Zamani-Farahani, H., \& Henderson, J. C. (2010). Islamic tourism and managing tourism development in Islamic societies: the cases of Iran and Saudi Arabia. International journal of tourism research, 12(1), 79-89. 